OPEN ACCESS

Edited by:

Andrea Guzzetta,

University of Pisa, Italy

Reviewed by:

D. Mishra,

Maulana Azad Medical College, India

Finn Lennartsson,

Lund University, Sweden

*Correspondence:

Jing Zhang

jzhang0000@gmail.com

Specialty section:

This article was submitted to

Neuropediatrics,

a section of the journal

Frontiers in Neurology

Received: 07 September 2017 Accepted: 11 December 2017

Published: 21 December 2017

Citation:

Zhang J (2017) Multivariate Analysis and Machine Learning in Cerebral

Palsy Research.

Front. Neurol. 8:715.

doi: 10.3389/fneur.2017.00715

\section{Multivariate Analysis and Machine Learning in Cerebral Palsy Research}

\author{
Jing Zhang* \\ Department of Neurology, Washington University in St. Louis, St. Louis, MO, United States
}

Cerebral palsy (CP), a common pediatric movement disorder, causes the most severe physical disability in children. Early diagnosis in high-risk infants is critical for early intervention and possible early recovery. In recent years, multivariate analytic and machine learning (ML) approaches have been increasingly used in CP research. This paper aims to identify such multivariate studies and provide an overview of this relatively young field. Studies reviewed in this paper have demonstrated that multivariate analytic methods are useful in identification of risk factors, detection of $\mathrm{CP}$, movement assessment for $\mathrm{CP}$ prediction, and outcome assessment, and ML approaches have made it possible to automatically identify movement impairments in high-risk infants. In addition, outcome predictors for surgical treatments have been identified by multivariate outcome studies. To make the multivariate and $\mathrm{ML}$ approaches useful in clinical settings, further research with large samples is needed to verify and improve these multivariate methods in risk factor identification, CP detection, movement assessment, and outcome evaluation or prediction. As multivariate analysis, ML and data processing technologies advance in the era of Big Data of this century, it is expected that multivariate analysis and ML will play a bigger role in improving the diagnosis and treatment of $\mathrm{CP}$ to reduce mortality and morbidity rates, and enhance patient care for children with CP.

Keywords: multivariate analysis, machine learning, cerebral palsy, early diagnosis, outcome assessment

\section{INTRODUCTION}

Cerebral palsy (CP) is the most common movement disorder in children (1) and causes the most severe physical disability in neurodevelopmental disorders (2). Among children with $\mathrm{CP}$, around $33 \%$ of them can not walk, $25 \%$ can not talk, $25 \%$ have epilepsy, $50 \%$ have an intellectual disability, and most of them are in pain (3). Spastic CP is the most common subtype of this disorder, often shown as muscle stiffness that causes movement difficulties in a hand, arm, foot, or leg on one or both sides of the body, affecting the majority (>85\%) of children with CP (4). Other subtypes of CP include dyskinetic (athetoid or dystonic) CP, ataxic CP (e.g., with tremors), and mixed CP.

Currently, there is no cure for CP, but medications (such as baclofen and botulinum toxin), supportive treatments (such as physical therapy), and surgical procedures [such as orthopedic surgery and selective dorsal rhizotomy (SDR)] can help patients alleviate symptoms and improve motor skills (5). The signs and symptoms of $\mathrm{CP}$ usually appear in the early months of life, but the average age for diagnosis of CP is around 2 years (2). Therefore, early identification and intervention is crucial for patients with CP because infants have higher potential for recovery from neural lesions than adults $(1,2)$. Neuroimaging, motor assessment (such as general movement assessment), and neurological examinations can help identify high-risk infants, monitor 
neurodevelopment, and detect or predict CP. Neuroimaging such as magnetic resonance imaging (MRI) and cranial ultrasound are useful to detect structural changes [intraventricular hemorrhage, periventricular leukomalacia (PVL), etc.] in the newborn brain, monitor lesion progression, and assess treatment effects, although compared with MRI, cranial ultrasound is less sensitive to lesions in the gray matter or malformations. Severe CP (caused by severe brain lesions such as PVL) can be identified by MRI or cranial ultrasound as soon as the lesions become recognizable on imaging after birth. However, $12-14 \%$ of children with CP have negative MRI scans due to subtle lesions in the brain (6). Thus, an integrated approach (imaging, motor assessment and neurological examinations) is needed to predict mild or moderate CP.

To predict CP in infants, Prechtl has described a general movement assessment method as a clinical assessment approach to identify CP motor impairments in infants by evaluating their spontaneous general movements (7). In particular, two atypical motor development features [(1) the presence of crampedsynchronized general movements at a preterm or term age and (2) the absence of small smooth movements or fidgety movements at 3-5 months] have been defined (8-10), which can identify CP in high-risk infants reliably (11). However, only well-trained physicians can perform such assessment, and general movement assessment based on visual observation by physicians is often influenced by subjective impressions and observer fatigue. Therefore, there is growing interest in developing multivariate and machine learning (ML)-based movement assessment tools for a more objective and quantitative motor assessment to detect movement impairments in high-risk infants $(12,13)$.

Multivariate analysis is a statistical analytical approach that simultaneously evaluates multiple variables, which compared with univariate analysis, may have more advantages (e.g., free from restrictions of various assumptions in univariate analysis) in identifying the associations between multiple data variables (e.g., variables associated with CP outcomes), grouping data into different groups or subgroups (e.g., different CP subtypes), and developing new diagnostic tests (e.g., differentiate CP subtypes with key feature variables). Multivariate analysis includes statistical methods such as principal components analysis (PCA), canonical variate analysis, independent components analysis, and multivariate regression. ML (or statistical learning) is a group of multivariate analytic methods that first identify the most significant data features or patterns that can best separate the data into different classes in the training dataset, and then apply these data features or patterns to the test dataset for data classification or prediction. ML has been increasingly applied to the biomedical field $(14,15)$, and examples of ML methods include linear discriminate analysis (16), support vector machine (SVM) (17), artificial neural networks (ANN) (18), random forest (19), and cluster analysis (20).

With growing interests, multivariate analysis has been increasingly employed in $\mathrm{CP}$ research in recent years, and research with multivariate analyses in $\mathrm{CP}$ is in infancy (14). To provide an overview of this relatively young field, PubMed search was performed with keywords "multivariate analysis cerebral palsy pediatric," "machine learning cerebral palsy," or "multivariate analysis cerebral palsy imaging." The search yielded 126 articles. Articles were excluded if their subjects were not pediatric or the statistical methods used were not multivariate or the article was published before year 1990. This paper assessed the studies that used multivariate analysis in $\mathrm{CP}$ research and found that multivariate studies in CP are mainly in four categories: (1) risk factor identification; (2) detection of CP and identification of CP abnormalities; (3) movement assessment for CP prediction; and (4) outcome evaluation.

\section{MULTIVARIATE ANALYSIS IN RISK FACTOR IDENTIFICATION}

Early work on CP risk factor identification started from birth certificates. In a large population-based cohort study, data from birth certificates for 192 children with CP in four counties in California were compared with 155,636 healthy children in the same regions and the study found that low birth weight and (early or late) gestational age at birth were associated with high prevalence of CP, but early prenatal care and delivery at a hospital (for low birth weight neonates) were not associated prevalence of $\mathrm{CP}$ (21). Using multivariate analysis on clinical data of $113 \mathrm{CP}$ infants (identified from 1,105 infants), Pinto-Martin et al. found that in low birth weight infants, cranial ultrasound imaging abnormalities such as parenchymal echodensities/lucencies (or ventricular enlargement) and germinal matrix/intraventricular hemorrhage were strong risk factors for disabling $\mathrm{CP}$, but factors such as birth weight, gestational age, and Apgar score were not associated with it (22). In addition, a multicenter, large sample study (across eight European study centers, $n=585$ ) revealed that there was a high rate of infection in mothers of $\mathrm{CP}$ children during their pregnancy and major CP abnormalities on structural MRI included white-matter damage due to immaturity (e.g., PVL) (42.5\%), lesions in the basal ganglia (12.8\%), cortical or subcortical lesions (9.4\%), and malformation (9.1\%) (23). A number of studies that identified CP risk factors have performed both univariate and multivariate analyses (24-26) where the risk factors identified by multivariate analyses were a subset of those identified by univariate analyses $(24,25)$, and the results of multivariate analyses were more rigorous and valid.

Studies that applied multivariate analysis to $\mathrm{CP}$ risk factor identification are summarized in Table $\mathbf{1}(22,24-31)$. Multivariate logistic regression has often been used to identify risk factors for CP $(22,26,29-31)$. Some of the risk factors identified by multivariate analytic studies include: premature birth, low birth weight, severe birth asphyxia, preterm rupture of membrane, abnormal cranial ultrasound, or structural MRI imaging findings (e.g., parenchymal echodensities/lucencies, or ventricular enlargement), intraventricular hemorrhage, PVL, neonatal sepsis, hypoxia-ischemic encephalopathy, hypoglycemia, neonatal jaundice, etc. (22-31). These risk factors are useful to understand the causes of $\mathrm{CP}$, identify high-risk infants, and aid in the diagnosis of CP.

Further, the risk factors for $\mathrm{CP}$ revealed by the multivariate studies are useful to prevent CP. Several CP risk factors such 
TABLE 1 | Summary of studies with multivariate analyses in identification of risk factors and detection of CP.

\begin{tabular}{|c|c|c|c|c|c|}
\hline Study & Subject sample & Data & Methods & Main findings & Other findings \\
\hline $\begin{array}{l}\text { Pinto-Martin } \\
\text { et al. (22) }\end{array}$ & $\begin{array}{l}113 \text { children with } \\
\mathrm{CP}\end{array}$ & $\begin{array}{l}\text { Clinical data (birth weight, } \\
\text { gestational age, length } \\
\text { of hospital stay, gender, } \\
\text { race, plurality, presence } \\
\text { of labor, Apgar score, } \\
\text { motor function, cranial US } \\
\text { findings, etc.) }\end{array}$ & $\begin{array}{l}\text { Multivariate logistic } \\
\text { regression to assess } \\
\text { risk factors for } \mathrm{CP}\end{array}$ & $\begin{array}{l}\text { Risk factors for disabling CP: PELNE } \\
\text { or ventricular enlargement on cranial } \\
\text { US, germinal matrix/intraventricular } \\
\text { hemorrhage, mechanical ventilation; } \\
\text { risk factors for non-disabling CP: } \\
\text { PELNE }\end{array}$ & $\begin{array}{l}\text { Cranial US abnormalities } \\
\text { are strong risk factors for } \\
\text { disabling CP in low birth } \\
\text { weight infants; non-risk } \\
\text { factors for disabling CP: } \\
\text { birth weight, gestational } \\
\text { age, length of hospital } \\
\text { stay, gender, race, plurality, } \\
\text { presence of labor, Apgar } \\
\text { score }\end{array}$ \\
\hline Allan et al. (24) & $\begin{array}{l}36 \text { pts with CP (in } \\
381 \text { infants) }\end{array}$ & $\begin{array}{l}\text { Clinical data (birth weight, } \\
\text { bronchopulmonary } \\
\text { dysplasia, abnormal } \\
\text { cranial US findings, } \\
\text { treatment, etc.) }\end{array}$ & $\begin{array}{l}\text { Univariate and } \\
\text { multivariate analysis to } \\
\text { identify antecedents } \\
\text { of CP }\end{array}$ & $\begin{array}{l}\text { Predictors of CP: bronchopulmonary } \\
\text { dysplasia and an abnormal cranial } \\
\text { US scan (showing grade } 3 \text { to } 4 \\
\text { intraventricular hemorrhage, PVL, or } \\
\text { ventriculomegaly) }\end{array}$ & $\begin{array}{l}\text { PVL and ventriculomegaly } \\
\text { associated with high } \\
\text { CP detection rates; } \\
\text { chorioamnionitis and } \\
\text { treatment with surfactant } \\
\text { significant in univariate } \\
\text { analysis }\end{array}$ \\
\hline
\end{tabular}

\begin{tabular}{|c|c|c|c|c|c|}
\hline Kim et al. (25) & 35 pts with $\mathrm{CP}$ & $\begin{array}{l}\text { Clinical data (age, weight, } \\
\text { neonatal sepsis, neonatal } \\
\text { seizure, etc.) }\end{array}$ & $\begin{array}{l}\text { Univariate and } \\
\text { multivariate analysis } \\
\text { to identify risk factors } \\
\text { for CP }\end{array}$ & $\begin{array}{l}\text { Risk factors for CP and delayed } \\
\text { development: neonatal sepsis }\end{array}$ & \\
\hline Han et al. (27) & 21 children with CP & $\begin{array}{l}\text { Clinical data (birth } \\
\text { characteristics, disease } \\
\text { at birth, neonatal cerebral } \\
\text { ultrasound findings, etc.) }\end{array}$ & $\begin{array}{l}\text { Multivariate analysis } \\
\text { used to identify risk } \\
\text { factors for } \mathrm{CP}\end{array}$ & $\begin{array}{l}\text { Risk factors for CP: existence of } \\
\text { PVL, preterm labor, preterm rupture } \\
\text { of membrane, severe birth asphyxia, } \\
\text { neonatal sepsis, and respiratory } \\
\text { distress syndrome }\end{array}$ & $\begin{array}{l}\text { Existence of } \mathrm{PVL} \text { is the } \\
\text { strongest risk factor for } \mathrm{CP}\end{array}$ \\
\hline Zhong et al. (28) & $\begin{array}{l}308 \text { children with } \\
\mathrm{CP}\end{array}$ & $\begin{array}{l}\text { Data from a cross- } \\
\text { sectional survey (birth } \\
\text { characteristics, disease } \\
\text { during the first month of } \\
\text { life, etc.) }\end{array}$ & $\begin{array}{l}\text { Multivariate analysis } \\
\text { used to identify risk } \\
\text { factors for } \mathrm{CP}\end{array}$ & $\begin{array}{l}\text { Risk factors for CP: delivery at home, } \\
\text { low Apgar score, illness during the } \\
\text { first month of life, maternal cold } \\
\text { with fever in early gestation, low } \\
\text { protein intake during pregnancy, low } \\
\text { education level of mother }\end{array}$ & \\
\hline Golomb et al. (26) & $\begin{array}{l}76 \text { children with } \\
\text { CP after perinatal } \\
\text { stroke }\end{array}$ & $\begin{array}{l}\text { Clinical data (perinatal } \\
\text { history, motor function, } \\
\text { frequency of CP, degree } \\
\text { of disability, etc.) }\end{array}$ & $\begin{array}{l}\text { Univariate and } \\
\text { multivariate analysis } \\
\text { (with logistic regression) } \\
\text { to assess risk factors for } \\
\text { CP in perinatal stroke }\end{array}$ & $\begin{array}{l}68 \% \text { pts with perinatal stroke had CP; } \\
\text { risk factors for CP: delayed stroke } \\
\text { and male gender; In pts with neonatal } \\
\text { stroke, risk factors for triplegia or } \\
\text { quadriplegia: bilateral infarcts }\end{array}$ & $\begin{array}{l}\text { In pts with unilateral middle } \\
\text { cerebral artery infarcts, risk } \\
\text { factors for CP: delayed } \\
\text { stroke and large-branch } \\
\text { infarction }\end{array}$ \\
\hline Miamoto et al. (29) & $\begin{array}{l}60 \text { pts with CP vs. } \\
60 \text { healthy controls }\end{array}$ & $\begin{array}{l}\text { Data from questionnaires } \\
\text { and clinical exams } \\
\text { (TMD symptoms, } \\
\text { bio-psychosocial } \\
\text { characteristics, etc.) }\end{array}$ & $\begin{array}{l}\text { Multivariate logistic } \\
\text { regression to determine } \\
\text { risk factors for TMD } \\
\text { symptoms }\end{array}$ & $\begin{array}{l}\text { Risk factors for TMD symptoms: } \\
\text { presence of } \mathrm{CP} \text {, male gender, severity } \\
\text { of the malocclusion, mouth breathing, } \\
\text { and mixed dentition }\end{array}$ & $\begin{array}{l}13.3 \% \text { pts vs. } 1.7 \% \text { controls } \\
\text { had TMD symptoms }\end{array}$ \\
\hline Abdullahi et al. (30) & $\begin{array}{l}111 \text { pts with CP vs. } \\
222 \text { controls }\end{array}$ & $\begin{array}{l}\text { Clinical data (maternal } \\
\text { sociodemographic } \\
\text { characteristics and } \\
\text { neonatal expected } \\
\text { predictors) }\end{array}$ & $\begin{array}{l}\text { Univariate and } \\
\text { multivariate (logistic } \\
\text { regression) analyses } \\
\text { used to identify factors } \\
\text { associated with CP }\end{array}$ & $\begin{array}{l}\text { Predictors of CP: maternal fever, } \\
\text { previous neonatal death, and poor } \\
\text { sucking }\end{array}$ & $\begin{array}{l}\text { Factors not associated with } \\
\mathrm{CP} \text { : maternal age, parity, } \\
\text { birth weight, and sex }\end{array}$ \\
\hline Yu et al. (31) & $\begin{array}{l}203 \text { preterm infants } \\
\text { with CP, vs. } 220 \\
\text { preterm infants } \\
\text { without CP or } \\
\text { other neurological } \\
\text { disorders }\end{array}$ & $\begin{array}{l}\text { Data of diseases of } \\
\text { premature infants, the } \\
\text { treatments in neonatal } \\
\text { period, etc. }\end{array}$ & $\begin{array}{l}\text { Multivariate logistic } \\
\text { analysis used to identify } \\
\text { risk factors associated } \\
\text { with CP }\end{array}$ & $\begin{array}{l}\text { Risk factors for CP: occurrence of } \\
\text { PVL, HIE, hypoglycemia, or neonatal } \\
\text { jaundice }\end{array}$ & $\begin{array}{l}\text { Continuous positive airway } \\
\text { pressure may lower the risk } \\
\text { of } \mathrm{CP}\end{array}$ \\
\hline Golomb et al. (32) & $\begin{array}{l}76 \text { children with } \\
\text { CP after perinatal } \\
\text { stroke }\end{array}$ & $\begin{array}{l}\text { Clinical data (perinatal } \\
\text { history, motor function, } \\
\text { frequency of CP, degree } \\
\text { of disability, etc.) }\end{array}$ & $\begin{array}{l}\text { Univariate and } \\
\text { multivariate analysis } \\
\text { (with logistic regression) } \\
\text { to assess association of } \\
\text { CP with other disabilities }\end{array}$ & $\begin{array}{l}72 \% \text { pts with perinatal stroke had at } \\
\text { least another disability; risk factors for } \\
\text { epilepsy: neonatal presentation and } \\
\text { history of cesarean-section delivery }\end{array}$ & $\begin{array}{l}\text { Risk factors for severe } \\
\text { cognitive impairments or } \\
\text { epilepsy: perinatal stroke } \\
\text { with neonatal presentation }\end{array}$ \\
\hline
\end{tabular}


TABLE 1 | Continued

\begin{tabular}{|c|c|c|c|c|c|}
\hline Study & Subject sample & Data & Methods & Main findings & Other findings \\
\hline Griffiths et al. (33) & $\begin{array}{l}20 \text { pts with spastic } \\
\mathrm{CP} ; 20 \text { with } \\
\text { dyskinetic CP }\end{array}$ & $\begin{array}{l}\text { Injury severity scores at } \\
\text { different brain regions } \\
\text { on magnetic resonance } \\
\text { imaging (T2) }\end{array}$ & $\begin{array}{l}\text { Variables indicated } \\
\text { by univariate analysis } \\
\text { fed to multivariate } \\
\text { logistic regression to } \\
\text { identify predictors to } \\
\text { differentiate spastic and } \\
\text { dyskinetic CP }\end{array}$ & $\begin{array}{l}\text { Spastic CP pts had more severe } \\
\text { damage to white matter near the } \\
\text { paracentral lobule; dyskinetic CP pts } \\
\text { had more injury to the STN: hypoxic- } \\
\text { ischemic injury to the STN at birth } \\
\text { associated with dyskinetic CP }\end{array}$ & $\begin{array}{l}\text { Non-predictors of } \\
\text { dyskinesia: injuries to the } \\
\text { putamen, caudate, and } \\
\text { globus pallidus }\end{array}$ \\
\hline Yoshida et al. (34) & $\begin{array}{l}34 \text { pts with CP vs. } \\
21 \text { healthy subjects }\end{array}$ & $\begin{array}{l}\text { Parameters (number } \\
\text { of fibers, tract-based } \\
\text { FA, and FA) for CST } \\
\text { and posterior thalamic } \\
\text { radiation tracts from } \\
\text { diffusion tensor imaging } \\
\text { (DTI) and motor level data }\end{array}$ & $\begin{array}{l}\text { Univariate and } \\
\text { multivariate (regression) } \\
\text { analysis used to identify } \\
\text { variables correlated to } \\
\text { gross motor function }\end{array}$ & $\begin{array}{l}\text { Number of fibers and ROI-based } \\
\text { FA values of both tracts were lower } \\
\text { in pts than controls; motor-sensory } \\
\text { parameters were negatively correlated } \\
\text { with GMFCS level }\end{array}$ & \\
\hline Coppola et al. (35) & $\begin{array}{l}\text { Group 1: } 40 \text { pts } \\
\text { with CP and mental } \\
\text { retardation; group } \\
\text { 2: } 47 \text { pts with CP, } \\
\text { mental retardation } \\
\text { and epilepsy; } \\
\text { group 3: } 26 \text { pts } \\
\text { with epilepsy }\end{array}$ & $\begin{array}{l}\text { Clinical data (age, } \\
\text { BMI, BMD z-score } \\
\text { from dual-energy X-ray } \\
\text { absorptiometry scan, etc.) }\end{array}$ & $\begin{array}{l}\text { Multivariate analysis } \\
\text { used to identify factors } \\
\text { on BMD }\end{array}$ & $\begin{array}{l}\text { Lower BMD in } 42.5 \% \text { pts in group } 1 \text {, } \\
70.2 \% \text { in group } 2,11.5 \% \text { in group } 3 \\
\text { Factors on BMD: age, BMl, severe } \\
\text { mental retardation, epilepsy }\end{array}$ & $\begin{array}{l}\text { In pts with CP, mental } \\
\text { retardation and epilepsy, } \\
\text { epilepsy is an aggravating } \\
\text { factor on bone health }\end{array}$ \\
\hline Benfer et al. (36) & 120 pts with CP & $\begin{array}{l}\text { Data of OPD measures, } \\
\text { motor measures, etc. }\end{array}$ & $\begin{array}{l}\text { Univariate and } \\
\text { multivariate regression } \\
\text { analysis to determine } \\
\text { the relationship between } \\
\text { OPD and motor } \\
\text { functions }\end{array}$ & $\begin{array}{l}\text { Higher odds of OPD in non-ambulant } \\
\text { pts than in ambulant pts }\end{array}$ & $85 \%$ pts had OPD \\
\hline Romeo et al. (37) & $\begin{array}{l}100 \text { pts with CP } \\
\text { (32 of them with } \\
\text { epilepsy) vs. } 100 \\
\text { healthy children }\end{array}$ & $\begin{array}{l}\text { Data from the SDSC, } \\
\text { GMFCS levels, etc. }\end{array}$ & $\begin{array}{l}\text { Multivariate analysis } \\
\text { (logistic regression) } \\
\text { used to identify factors } \\
\text { associated with SDSC }\end{array}$ & $\begin{array}{l}\text { 13\% of children with CP had } \\
\text { abnormal sleep score; factors } \\
\text { associated with SDSC: behavioral } \\
\text { problems and epilepsy }\end{array}$ & $\begin{array}{l}\text { Compared with healthy } \\
\text { controls, sleep disorders are } \\
\text { more common in children } \\
\text { with CP }\end{array}$ \\
\hline Adler et al. (38) & $\begin{array}{l}18 \text { children with } \\
\text { unilateral spastic } \\
\text { CP ( } 9 \text { with mirror } \\
\text { movement, } 9 \\
\text { without) }\end{array}$ & $\begin{array}{l}\text { Clinical data from } \\
\text { BANIMM, JTHFT, and } \\
\text { AHA }\end{array}$ & $\begin{array}{l}\text { Multivariate analysis } \\
\text { of covariance used } \\
\text { to determine whether } \\
\text { mirror movements affect } \\
\text { daily living }\end{array}$ & $\begin{array}{l}\text { Mirror movements had a negative } \\
\text { impact on bimanual performance } \\
(\mathrm{AHA}) \text { and on the time needed to } \\
\text { complete difficult activities }\end{array}$ & \\
\hline Tao et al. (39) & $\begin{array}{l}11 \text { children with } \\
\text { CP, } 8 \text { healthy } \\
\text { children, } 7 \text { healthy } \\
\text { adults }\end{array}$ & $\begin{array}{l}\text { EMG data from five thigh } \\
\text { muscles and three lower } \\
\text { leg muscles }\end{array}$ & $\begin{array}{l}\text { Multivariate empirical } \\
\text { mode decomposition } \\
\text { enhanced MMSE } \\
\text { analysis used to analyze } \\
\text { EMG data; repeated- } \\
\text { measure ANOVAs for } \\
\text { group comparison }\end{array}$ & $\begin{array}{l}\text { Compared with the control group, } \\
\text { CP pts had distinct diversity in MMSE } \\
\text { curve }\end{array}$ & $\begin{array}{l}\text { Abnormal MMSE curve } \\
\text { reflected problems in } \\
\text { individual muscles such as } \\
\text { motor control impairments, } \\
\text { loss of muscle couplings, } \\
\text { and spasticity or paralysis }\end{array}$ \\
\hline Ghate et al. (40) & 54 pts with $\mathrm{CP}$ & $\begin{array}{l}\text { Clinical data (CP } \\
\text { type, motor function, } \\
\text { etc.) and data from } \\
\text { ophthalmoscopic } \\
\text { examinations }\end{array}$ & $\begin{array}{l}\text { Multivariate logistic } \\
\text { regression to identify } \\
\text { factors associated with } \\
\text { motor outcomes }\end{array}$ & $\begin{array}{l}70 \% \text { pts had abnormal optic nerve } \\
\text { head; disk pallor associated with non- } \\
\text { ambulatory status and quadriplegia; } \\
\text { large cup associated with age at } \\
\text { examination }\end{array}$ & $\begin{array}{l}\text { Indicator for poor motor } \\
\text { outcome: presence of optic } \\
\text { nerve head pallor }\end{array}$ \\
\hline Reid et al. (41) & $\begin{array}{l}31 \text { children with } \\
\text { unilateral CP }\end{array}$ & $\begin{array}{l}\text { Activation maps from } \\
\text { fMRI (with hand task); } \\
\text { FA and MD values } \\
\text { and fiber tracts in the } \\
\text { thalamocortical and } \\
\text { corticomotor tracts from } \\
\text { DTI; clinical scores of } \\
\text { motor ability }\end{array}$ & $\begin{array}{l}\text { k-means clustering } \\
\text { used to identify fMRI- } \\
\text { task-specific DTI tracks; } \\
\text { surface-based approach } \\
\text { (using surface-meshes) } \\
\text { compared with } \\
\text { voxelwise fMRI-DTI } \\
\text { approach; correlation } \\
\text { analysis between DTI } \\
\text { metrics and clinical } \\
\text { scores performed }\end{array}$ & $\begin{array}{l}\text { DTI metrics and five clinical scores } \\
\text { of motor function were correlated; } \\
\text { surface-based approach processed } \\
\text { more subjects' data ( } 87 \%) \\
\text { than the voxel-based approach } \\
\text { (65\%), generated more coherent } \\
\text { tractography }\end{array}$ & $\begin{array}{l}\text { Surface-based approach } \\
\text { revealed more significant } \\
\text { correlations between DTI } \\
\text { metrics and five clinical } \\
\text { scores }\end{array}$ \\
\hline
\end{tabular}


TABLE 1 | Continued

\begin{tabular}{|c|c|c|c|c|c|}
\hline Study & Subject sample & Data & Methods & Main findings & Other findings \\
\hline Tosun et al. (42) & $\begin{array}{l}30 \text { pts with CP } \\
\text { only; } 54 \text { pts } \\
\text { with epilepsy } \\
\text { only; } 38 \text { pts with } \\
\text { CP + epilepsy; } 30 \\
\text { healthy children }\end{array}$ & $\begin{array}{l}\text { BMD of lumbar vertebrae } \\
\text { obtained by dual energy } \\
\text { X-ray absorptiometry; } \\
\text { clinical data (dietary } \\
\text { Ca intake, whether } \\
\text { intellectual disability, } \\
\text { whether immobility, etc.) }\end{array}$ & $\begin{array}{l}\text { Multivariate regression } \\
\text { analysis used to } \\
\text { evaluate the relationship } \\
\text { between BMD and } \\
\text { possible risk factors }\end{array}$ & $\begin{array}{l}\text { Low BMD common in pts with CP } \\
\text { and CP + epilepsy; risk factor of low } \\
\text { BMD: immobility (not able to walk } \\
\text { independently) }\end{array}$ & $\begin{array}{l}\text { Low BMD related to the } \\
\text { severity of } C P \text {, but not to } \\
\text { vitamin } D \text { levels or AED } \\
\text { treatment }\end{array}$ \\
\hline
\end{tabular}

AHA, assisting hand assessment; BANIMM, bimanual activities negatively influenced by mirror movements; BMD, bone mineral density; BMI, body mass index; CST, corticospinal tract; CP, cerebral palsy; EMG, electromyographic; FA, fractional anisotropy; GMFCS, Gross Motor Function Classification System; HIE, hypoxia-ischemic encephalopathy; JTHFT, Jebsen taylor hand function test; MD, mean diffusivity; MMSE, multivariate multi-scale entropy; OPD, oropharyngeal dysphagia; PELNE, parenchymal echodensities/lucencies; Pts, patients; PVL, periventricular leukomalacia; ROI, region of interest; SDSC, Sleep Disturbance Scale for Children; STN, subthalamic nucleus; surgeon volume, the number of procedures performed; TMD, temporomandibular disorders; US, ultrasound.

as brain injury and infection can be managed and avoided by preventing their causative mechanisms, and preventive efforts such as rubella vaccination, anti-D vaccination, and preventing methylmercury contamination are effective in preventing CP (2). In addition, meta-analysis has indicated that $\mathrm{CP}$ may be reduced by $30 \%$ in premature infants ( $<32$ weeks gestation) by providing mothers of imminent-labor with magnesium sulfate for neuroprotection of their babies $(43,44)$. Further, early interventions such as hypothermia have prevented CP in $12.5 \%$ of infants with neonatal encephalopathy following an acute intrapartum hypoxic event (45). Since, currently, there is no cure for CP, CP prevention is critical to reduce the prevalence of $\mathrm{CP}$ and save children from $\mathrm{CP}$ and CP-caused life-long disabilities. Multivariate analysis may help identify significant risk factors and early interventions in order to prevent CP.

Taken together, multivariate analysis is important in identification of risk factors for $\mathrm{CP}$ and the risk factors identified such as premature birth and abnormal (cranial ultrasound or structural $\mathrm{MRI}$ ) imaging findings are useful not only for $\mathrm{CP}$ cause identification and diagnosis but also for CP prevention. Further research is needed to identify more manageable and avoidable risk factors and early interventions (such as neuroprotective drugs or therapies) to prevent $\mathrm{CP}$ and reduce $\mathrm{CP}$ morbidity rate.

\section{MULTIVARIATE ANALYSIS IN DETECTION OF CP AND IDENTIFICATION OF CP ABNORMALITIES}

Since the current average age for diagnosis of CP is around 2 years and infants have higher potential for neural recovery $(1,2)$, early detection of CP is critical to make early intervention possible. To identify $\mathrm{CP}$ in high-risk infants, neuroimaging such as cranial ultrasound and MRI is important for lesion detection and deciding the timing of the lesion. Studies applied multivariate analytic methods to detection of $\mathrm{CP}$ and identification of CP abnormalities are summarized in the latter part of Table 1 (32-42). A multicenter study of very-low birth weight infants $(n=381$, survival rate $=87 \%, 36$, or $9.4 \%$ with $\mathrm{CP}$ ) indicated that cranial ultrasound findings such as grade 3-4 intraventricular hemorrhage and PVL were useful in predicting $\mathrm{CP}$; in particular, PVL and ventriculomegaly were related to high detection rate ( $\geq 30 \%)$ for CP (24). Further, to differentiate CP subtypes, Griffiths et al. examined the
T2 MRI images of children with spastic or dyskinetic CP $(n=20$ in each group), and found that patients with spastic CP had more severe injury to white matter near the paracentral lobule, while patients with dyskinetic CP had more injury to the subthalamic nucleus (STN) (33). Multivariate logistic regression further identified the associated factors (i.e., lesions in distinctly different anatomical locations) for differentiation of spastic and dyskinetic CP (33).

When brain injuries in patients with CP are subtle, advanced imaging such as diffusion tensor imaging (DTI) and diffusionweighted imaging is useful to detect CP injuries with subtle abnormalities. DTI metrics such as mean diffusion (MD) and fractional anisotropy (FA) are often used to identify injuries in white matter tracts. The value of DTI in identifying degenerative changes in patients with spastic $\mathrm{CP}$ due to periventricular white matter injury has been demonstrated by an early study, which reported that children with spastic hemiparetic CP (caused by periventricular white matter injury) had reduced DTI fiber count on the ipsilateral (the same side as the lesion) side of the corticospinal tract (CST), corticobulbar tract (CBT), and superior thalamic radiation, and had $\mathrm{MD}$ and FA changes reflected neurodegeneration of the motor and sensory pathways $(n=5)$ (46). Further DTI studies found that white matter damage in the posterior thalamic radiation pathways was more severe than that in the CSTs in children with CP $(n=28)(47)$, and DTI abnormalities in several white matter tracts such as posterior thalamic radiation pathways or superior regions of the thalamocortical and corticomotor tracts correlated with motor function measured by, e.g., Gross Motor Function Classification System (GMFCS) level $(n=28-34)(34,41,47)$. A review paper summarized the results of 22 DTI studies in CP and reported common findings of decrease FA (or increased $\mathrm{MD}$ ) in the corticomotor and sensorimotor pathways, which correlated with clinical measures (48). Some research findings suggested that the CP injury in the somatosensory circuits might be more severe than that in the motor circuits, which may contribute more to motor impairment in CP (49). Further research is needed to unfold the mechanisms underlie sensorimotor impairment in CP and to improve detection of CP through neuroimaging.

Apart from neuroimaging, the abnormalities of $\mathrm{CP}$ have been identified via multivariate analysis using patients' clinical data (perinatal history, CP type, CP frequency, motor function, 
degree of disability, etc.) and data from other sources such as electromyography (EMG) and bone mineral density (BMD) (32, 35-40, 42). For example, multivariate analyses have indicated that $85 \%$ of $\mathrm{CP}$ patients have oropharyngeal dysphagia (36), 13\% have sleep disturbance (37), 70\% have abnormal optic nerve head (40), and 50\% have low BMD (42). Factors associated with these CP abnormalities have also been identified $(35,37,39)$.

In addition, since neonatal encephalopathy can cause $\mathrm{CP}$, detection of neonatal encephalopathy helps detect potential CP. Structural brain connectivity networks of infants with neonatal encephalopathy have been examined using diffusion tractography extracted from DTI images, and ML methods such as SVM have been applied to structural connectivity features to detect neonatal encephalopathy (50). Moreover, since epilepsy and seizure disorders are common in children with CP, electroencephalography (EEG) is used to detect co-occurring seizures in high-risk infants or children. ML approaches such as SVM and ANN have been applied to EEG features to identify ictal and interictal spikes and achieved high detection rate for seizures (51). Further, multivariate analysis has found that children with CP after perinatal or neonatal stroke are more likely to have severe disability, cognitive impairment or epilepsy than $\mathrm{CP}$ children after delayed stroke (32).

Taken together, multivariate analytic studies in CP detection have identified imaging markers such as intraventricular hemorrhage and PVL on cranial ultrasound (24), injury to white matter near the paracentral lobule or to the STN on T2 MRI images (33), and injury in the CSTs and the posterior thalamic radiation pathways on DTI images $(34,41,46,47)$, which are useful in detecting $\mathrm{CP}$ and differentiating $\mathrm{CP}$ subtypes. Multivariate analyses have also identified $\mathrm{CP}$ abnormalities and their associated factors from non-imaging data $(32,35-40,42)$. Further research is needed to identify biomarkers at the early stages of the disease to improve the diagnosis of CP, reduce diagnosis delay, and allow early identification and intervention for CP.

\section{IN MOVEMENT ASSESSMENT FOR CP PREDICTION}

Studies reported applications of ML in movement assessment for CP prediction are summarized in Table 2 (52-61). Early identification of motor impairments in high-risk infants enables early detection of CP. The two atypical movement features (related to the cramped-synchronized general movements and the absence of fidgety movements) in general movement assessment are strong predictors for CP diagnosis (8-10). Based on these key motor impairment features, their movement characteristics and associated movement variables have been identified to detect movement impairments in high-risk infants (53-55, 57-59). ML approaches have made it possible to analyze recorded movement data and identify motor impairments automatically.

As a pioneer study, Meinecke et al. analyzed the 3D movement data of infants $(n=22$, seven with $\mathrm{CP})$ from video recordings, extracted an optimal combination of movement features with cluster analysis, and identified CP motor impairments with quadratic discriminant analysis (overall detection rate: 73\%) (52). Further, the characteristics of fidgety movements and associated movement measurements have been identified to distinguish infants with movement impairments from those without $(53,54,58)$. For example, extracting motion features related to fidgety movements (such as motion distance and relative frequency) from video recordings with an optical flow-based method, Stahl et al. examined the motion patterns of 82 infants (15 with CP), applied SVM classifier to detection of CP movement impairments, and achieved a good classification accuracy $(93.7 \pm 2.1 \%$ with features of relative frequency; sensitivity: $85.3 \pm 2.8 \%$; specificity: $95.5 \pm 2.5 \%)(58)$.

Apart from video recordings, other movement recording systems such as accelerometers and electromagnetic movement tracking system have been employed for movement assessment and CP prediction. Heinze et al. examined the general movements of a group of newborns and infants $(n=23,4$ with CP) with accelerometers, selected optimal (combined) movement features with genetic algorithm, classified CP motor impairments with a decision tree-based classifier, and obtained overall detection rates of $88-92 \%$ (55). To distinguish the gait patterns between patients with CP $(n=4)$, patients with multiple sclerosis $(n=4)$, and healthy controls $(n=12)$, Alaqtash et al. extracted gait features from $3 \mathrm{D}$ ground reaction force data, compared the gait patterns of the three groups, and applied nearest-neighbor classifier and ANN to gait feature classification, which led to overall classification accuracies of $85 \%$ (ANN, with a combination of gait features) and 95\% (after optimizing the gait features to an optimal set of six gait features) (56). Moreover, using electromagnetic movement tracking recordings, Karch et al. studied the general movements from 63 infants (10 with $\mathrm{CP}$ ), extracted movement features such as joint centers, and computed stereotype scores with dynamic time warping, yielding a high CP classification accuracy with stereotype score of upper lime movement (sensitivity: 90\%; specificity: 96\%) (57). For a review on movement recognition techniques in general movement assessment for CP prediction in high-risk infants, see Ref. (12).

In addition, multivariate and ML approaches have been used in the assessment of physical therapy, and the effect of orthotic devices such as ankle foot orthosis on CP patients $(55,56)$. To evaluate the quality of exercises in $\mathrm{CP}$ physical therapy, Parmar and Morris $(n=5)$ applied four classifiers (SVM, neural networks, AdaBoosted decision tree, and dynamic time warping) to movement feature (joint and angle data in time or frequency domain) classification to identify correct or wrong exercise, and found that among the four classifiers, AdaBoosted decision tree performed the best with high classification accuracies $(94.68 \%$ for joint data; 90.3\% for angle data) (56).

However, these machine-learning-based movement assessment studies are at the early stage of research. For example, the subjects in the study of Alaqtash et al. (56) were healthy subjects $(n=5)$, the movement data of wrong exercises (with errors) were simulated data, thus, the results were preliminary. Further research is needed to apply machine-learning methods to real movement data of patients with CP. In addition, the sample sizes of patients with $\mathrm{CP}$ in these machine-learning-based 
TABLE 2 | Summary of studies with multivariate analytic and machine learning approaches in movement assessment and outcome evaluation in CP.

\begin{tabular}{|c|c|c|c|c|c|}
\hline Study & Subject sample & Data & Methods & Main findings & Other findings \\
\hline $\begin{array}{l}\text { Meinecke } \\
\text { et al. (52) }\end{array}$ & $\begin{array}{l}22 \text { infants ( } 7 \text { at risk } \\
\text { of } C P, 15 \text { healthy) }\end{array}$ & $\begin{array}{l}53 \text { parameters extracted } \\
\text { from recorded 3D movement } \\
\text { data }\end{array}$ & $\begin{array}{l}\text { Cluster analysis based on } \\
\text { Euclidian distances and } \\
\text { quadratic discriminant analysis } \\
\text { used to find the best combined } \\
\text { parameters and separate at } \\
\text { risk infants from healthy ones }\end{array}$ & $\begin{array}{l}\text { Overall detection rate (using } \\
\text { an optimal combination of } 8 \\
\text { parameters): } 73 \% \text { (sensitivity: } 1.00 \text {; } \\
\text { specificity: } 0.70 \text { ) }\end{array}$ & \\
\hline
\end{tabular}

\begin{tabular}{lll}
\hline Berge et al. & 14 infants with & Motion features (1D, 2D, and \\
(53) & CP (who had four & Wigner-Ville time-frequency \\
& $\begin{array}{ll}\text { types of fidgety } & \text { virtue/feature) extracted } \\
\text { movements) } & \text { from video recordings of } \\
& \text { movements }\end{array}$
\end{tabular}

Periodicity (fidgety

movements characterized by

periodic patterns); principal

components analysis (PCA)

ENIGMA (a software tool) can

assess general movements and

detect fidgety movements in $\mathrm{CP}$

for data reduction; Pattern

pts

recognition (compare

movement patterns in video

with known visual patterns of

fidgety movements)

\begin{tabular}{|c|c|c|c|}
\hline $\begin{array}{l}\text { Adde et al. } \\
\text { (54) }\end{array}$ & $\begin{array}{l}30 \text { high-risk preterm } \\
\text { and term infants } \\
\text { (13 developed } \mathrm{CP} \\
\text { in } 5 \text { years vs. } 17 \\
\text { non-CP) }\end{array}$ & $\begin{array}{l}\text { Movement variables (e.g., } \\
\text { quantity of motion, and } \\
\text { centroid of motion to identify } \\
\text { fidgety movements) extracted } \\
\text { from video recordings }\end{array}$ & $\begin{array}{l}\text { Mann-Whitney } U \text { test; Logistic } \\
\text { regression to identify } \mathrm{CP} \\
\text { predictors; } \mathrm{ROC} \text { analysis } \\
\text { to assess } \mathrm{CP} \text { classification } \\
\text { accuracy }\end{array}$ \\
\hline
\end{tabular}

\begin{tabular}{lll}
\hline Heinze et al. & 4 infants with CP, & 32 features (including velocity \\
(55) & $\begin{array}{l}\text { vs. } 19 \text { healthy } \\
\text { infants }\end{array}$ & $\begin{array}{l}\text { and acceleration) extracted } \\
\text { from measurement of } \\
\text { accelerometers }\end{array}$
\end{tabular}

Optimal parameter

combinations selected by

genetic algorithm; a decision

tree-based classifier used to

differentiate between pts' and

controls' data

\begin{tabular}{lll}
\hline $\begin{array}{l}\text { Alaqtash } \\
\text { et al. (56) }\end{array}$ & $\begin{array}{l}\text { 4 pts with spastic } \\
\text { diplegic CP, vs. 4 } \\
\text { pts with multiple } \\
\text { sclerosis, vs. 12 } \\
\text { healthy controls }\end{array}$ & $\begin{array}{l}\text { Gait features extracted from } \\
\text { 3D ground reaction force } \\
\text { data }\end{array}$ \\
\hline $\begin{array}{l}\text { Karch et al. } \\
\text { (57) }\end{array}$ & $\begin{array}{l}\text { 10 infants with } \\
\text { spastic CP, vs. 53 } \\
\text { non-CP infants }\end{array}$ & $\begin{array}{l}\text { Stereotypy score of limb } \\
\text { movements extracted from } \\
\text { electromagnetic movement } \\
\text { tracking recordings }\end{array}$ \\
& &
\end{tabular}

NNC and ANN used to classify gait features into three groups; leave-one-out resampling

$1 / 13$ of pts had fidgety movements; Combined variable had predictor of CP: combined variable the highest prediction (centroid of motion STD, quantity accuracy; ambulatory and of motion mean, quantity of motion non-ambulatory function STD); prediction accuracy of the was predicted correctly in combined variable: sensitivity: $85 \% ; \quad 90 \%$ pts with CP specificity: $88 \%$

Overall detection rate: $88-92 \%$ for The low-cost movement
all measurements disorder detection system based on accelerometers is applicable to CP diagnosis in newborns

Classification accuracy (weighted

average): $85 \%$ (using a combination of gait features); $95 \%$ (using an optimal set of six features)

\section{A multi-segmental chain model used to calculate the joint centers and joint axes; dynamic time warping used to compute stereotype scores; ROC analysis used to assess CP classification accuracy}

\begin{tabular}{lll}
\hline Stahl et al. & 82 infants (15 with & Motion features (such as \\
(58) & CP, 67 healthy) & motion distance and relative \\
& & frequency) extracted from \\
& video movement recordings
\end{tabular}

\begin{tabular}{lll}
\hline $\begin{array}{l}\text { Kanemaru } \\
\text { et al. (59) }\end{array}$ & $\begin{array}{l}\text { 145 preterm infants } \\
\text { (16 developed CP } \\
\text { by 3 years of age, } \\
\text { vs. 129 normal) }\end{array}$ & $\begin{array}{l}\text { 6 movement indices (average } \\
\text { velocity of limb movement, } \\
\text { number of movement units, } \\
\text { kurtosis of acceleration, jerk } \\
\text { index, etc.) extracted from } \\
\text { video recordings }\end{array}$ \\
\hline $\begin{array}{l}\text { Wahid et al. } \\
\text { (60) }\end{array}$ & $\begin{array}{l}\text { 51 children with } \\
\text { diplegic CP vs. 34 } \\
\text { healthy controls }\end{array}$ & $\begin{array}{l}\text { Spatiotemporal gait data } \\
\text { (physical properties, walking } \\
\text { speed, etc.) }\end{array}$ \\
& &
\end{tabular}

CP classification accuracy using
stereotype score of upper lime
movement: sensitivity: $90 \%$;
specificity: $96 \%$
Using stereotype score of leg movement could not distinguish pts from controls Motion features selected to identify fidgety movements; SVM used to classify pts from controls; 10-fold cross-validation for classifier validation

Fisher's exact test and MannWhitney $U$-test to distinguish pts from controls

Classification accuracy: with features of relative frequency: $93.7 \pm 2.1 \%$; sensitivity: $85.3 \pm 2.8 \%$; specificity: $95.5 \pm 2.5 \%$

CP pts had higher jerk index in the legs $(p<0.01)$, average velocity of the arms $(p<0.05)$, and number of movement units of the arms $(p<0.05)$ than controls

Multiple regression
normalization and standard
dimensionless equations used
for data normalization; multiple
regression normalization to
identify the effects of AFO on
gait in pts

Multiple regression normalization revealed difference in more spatiotemporal parameters in pts who walked with and without an AFO; after multiple regression normalization, most spatiotemporal parameters in pts with AFO became closer to those of controls

\section{Classification with other} features (absolute motion distance and wavelet coefficient) had lower accuracy

Jerkiness of spontaneous movements in preterm infants at term age is useful for predicting CP

Multiple regression normalization may be useful in evaluating CP gait and gait classification 
TABLE 2 | Continued

\begin{tabular}{|c|c|c|c|c|c|}
\hline Study & Subject sample & Data & Methods & Main findings & Other findings \\
\hline $\begin{array}{l}\text { Parmar and } \\
\text { Morris (61) }\end{array}$ & $\begin{array}{l}5 \text { healthy subjects } \\
\text { (who did exercises } \\
\text { correctly, and also } \\
\text { mimic the errors/ } \\
\text { mistakes in exercise } \\
\text { made by CP pts) }\end{array}$ & $\begin{array}{l}\text { Features (joint positions, } \\
\text { angles) in the time domain } \\
\text { (also transformed to the } \\
\text { frequency domain) extracted } \\
\text { from } 78 \text { training samples } \\
\text { and } 47 \text { testing samples of } \\
\text { physical exercises video } \\
\text { recording }\end{array}$ & $\begin{array}{l}4 \text { classifiers (SVM, NN, } \\
\text { AdaBoosted decision tree, } \\
\text { and DTW) used to distinguish } \\
\text { good and erroneous exercises } \\
\text { (in five sample exercises such } \\
\text { as Blast-Off exercise in CP } \\
\text { physical therapy) }\end{array}$ & $\begin{array}{l}\text { Classification accuracy: } 94.68 \% \\
\text { for AdaBoosted tree on joint data } \\
\text { (in time domain); } 90.89 \% \text { for } \\
\text { SVM on joint data (in frequency } \\
\text { domain); } 90.65 \% \text { for SVM on joint } \\
\text { data (in time domain); } 90.3 \% \text { for } \\
\text { AdaBoosted tree on angle data (in } \\
\text { time domain) }\end{array}$ & $\begin{array}{l}\text { Classification accuracy: } \\
90.13 \% \text { for single-layer } \\
\text { NN on joint data (in } \\
\text { time domain); } 87.63 \% \\
\text { for SVM on angle data } \\
\text { (in frequency domain); } \\
74.03 \% \text { for DTW on angle } \\
\text { data (in time domain) }\end{array}$ \\
\hline $\begin{array}{l}\text { Hemming } \\
\text { et al. (62) }\end{array}$ & $\begin{array}{l}\text { 4,007 children with } \\
\mathrm{CP}\end{array}$ & $\begin{array}{l}\text { Data from five CP registers } \\
\text { (birth characteristics, severity } \\
\text { of CP, level of impairment, } \\
\text { socioeconomic status, etc.) }\end{array}$ & $\begin{array}{l}\text { Kaplan-Meier survival } \\
\text { estimates performed; } \\
\text { Multivariate proportional } \\
\text { hazards model fitted for } \\
\text { survival analysis }\end{array}$ & $\begin{array}{l}\text { Death rate: } \sim 8 \% \text {; rate of children } \\
\text { who survived to } 20 \text { years of age: } \\
85-94 \% \text {; predictors of CP survival: } \\
\text { The number and severity of } \\
\text { impairment }\end{array}$ & $\begin{array}{l}\text { Birth weight and } \\
\text { socioeconomic status } \\
\text { might have impact on } \\
\text { survival in certain register } \\
\text { regions }\end{array}$ \\
\hline Kim et al. (63) & $\begin{array}{l}174 \text { children with } \\
\text { spastic CP who } \\
\text { underwent SDR }\end{array}$ & $\begin{array}{l}\text { Clinical data (age at surgery, } \\
\text { types of CP, history of } \\
\text { prematurity, motor function, } \\
\text { history of seizures, etc.) }\end{array}$ & $\begin{array}{l}\text { Univariate and multivariate } \\
\text { logistic regression used to } \\
\text { identify factors associated with } \\
\text { surgical outcome }\end{array}$ & $\begin{array}{l}\text { 6.3\% pts had a poor outcome; } \\
\text { predictor of outcome: type of CP } \\
\text { (diplegia, quadriplegia) }\end{array}$ & $\begin{array}{l}\text { Preoperative diagnosis } \\
\text { was a strong predictor; } \\
\text { intellectual delay was } \\
\text { significant only in } \\
\text { univariate analysis }\end{array}$ \\
\hline $\begin{array}{l}\text { Golan et al. } \\
(64)\end{array}$ & $\begin{array}{l}98 \text { pts with spastic } \\
\text { CP who underwent } \\
\text { SDR }\end{array}$ & $\begin{array}{l}\text { Data from hospital charts } \\
\text { and radiographic spinal } \\
\text { studies (preoperative and } \\
\text { postoperative) }\end{array}$ & $\begin{array}{l}\text { Univariate and multivariate } \\
\text { regression analyses used to } \\
\text { identify risk factors for spinal } \\
\text { deformity }\end{array}$ & $\begin{array}{l}\text { Risk factors for spinal deformity: } \\
\text { CP severity; ambulatory function; } \\
\text { age at surgery; gender }\end{array}$ & $\begin{array}{l}\text { Factors associated } \\
\text { with a lower rate of } \\
\text { hyperlordosis: younger } \\
\text { age at surgery and male } \\
\text { gender }\end{array}$ \\
\hline $\begin{array}{l}\text { Majnemer } \\
\text { et al. (65) }\end{array}$ & 95 children with CP & $\begin{array}{l}\text { Data from Child Health } \\
\text { Questionnaire and Pediatric } \\
\text { QOL Inventory (by pts and } \\
\text { parents), and measurements } \\
\text { (impairments, activity } \\
\text { limitations, etc.) }\end{array}$ & $\begin{array}{l}\text { Multivariate analysis used to } \\
\text { identify determinants of QOL }\end{array}$ & $\begin{array}{l}\text { Indicators of physical well-being: } \\
\text { motor and other activity limitations; } \\
\text { predictors of social-emotional } \\
\text { adaptation: family functioning, } \\
\text { behavioral difficulties, and } \\
\text { motivation }\end{array}$ & $\begin{array}{l}47 \% \text { pts had mild motor } \\
\text { impairment }\end{array}$ \\
\hline $\begin{array}{l}\text { White-Koning } \\
\text { et al. (66) }\end{array}$ & $\begin{array}{l}500 \text { children with } \\
\mathrm{CP} \text { (in } 7 \text { countries in } \\
\text { Europe) }\end{array}$ & $\begin{array}{l}\text { Data from the Kidscreen } \\
\text { questionnaire (by pts and } \\
\text { parents) }\end{array}$ & $\begin{array}{l}\text { Multivariate analysis used to } \\
\text { identify factors associated the } \\
\text { differences in parents' and pts' } \\
\text { reports }\end{array}$ & $\begin{array}{l}\text { Factors associated with the } \\
\text { differences in parents' and pts' } \\
\text { reports: high levels of stress in } \\
\text { parenting (negative influence), self- } \\
\text { reported severe child pain }\end{array}$ & $\begin{array}{l}\text { Pts' self-reports higher } \\
\text { than parents' in } 8 \text { domains, } \\
\text { lower in the finances } \\
\text { domain, and similar in the } \\
\text { emotions domain }\end{array}$ \\
\hline $\begin{array}{l}\text { Long et al. } \\
\text { (67) }\end{array}$ & $\begin{array}{l}71 \text { pts with CP } \\
\text { vs. } 77 \text { non-CP; all } \\
\text { subjects underwent } \\
\text { orthopedic surgery }\end{array}$ & $\begin{array}{l}\text { Demographic, surgical, and } \\
\text { medical data (intraoperative } \\
\text { opioid dosing, postoperative } \\
\text { ICU admission, postoperative } \\
\text { oxygen desaturation, etc.) }\end{array}$ & $\begin{array}{l}\text { Multivariate regression } \\
\text { analysis used to determine } \\
\text { intraoperative opioid dosing } \\
\text { associated outcomes and } \\
\text { other variables }\end{array}$ & $\begin{array}{l}\text { CP pts received less intraoperative } \\
\text { opioid than non-CP pts; predictors } \\
\text { of postoperative ICU admission and } \\
\text { postoperative oxygen desaturation: } \\
\text { intraoperative opioid dosing }\end{array}$ & $\begin{array}{l}\text { CP associated with } \\
\text { decreased opioid dosing }\end{array}$ \\
\hline $\begin{array}{l}\text { Smits et al. } \\
(68)\end{array}$ & 116 pts with CP & $\begin{array}{l}\text { 3-year longitudinal data } \\
\text { (motor function, intellectual } \\
\text { capacity, etc.) }\end{array}$ & $\begin{array}{l}\text { Univariate and multivariate } \\
\text { analyses to investigate } \\
\text { associations between the } \\
\text { course of capabilities (e.g., in } \\
\text { mobility) and CP-, child-, and } \\
\text { family characteristics }\end{array}$ & $\begin{array}{l}\text { Predictors of self-care: a model } \\
\text { including level of gross motor } \\
\text { function and intellectual capacity; } \\
\text { predictors of mobility: a model } \\
\text { only including level of gross motor } \\
\text { function; predictors of social } \\
\text { function: a model including level } \\
\text { of bimanual function and paternal } \\
\text { educational level }\end{array}$ & $\begin{array}{l}\text { Greater increase in } \\
\text { capabilities for higher level } \\
\text { of functioning, except for } \\
\text { level of paternal education }\end{array}$ \\
\hline $\begin{array}{l}\text { Sponseller } \\
\text { et al. (69) }\end{array}$ & $\begin{array}{l}204 \text { pts with CP } \\
\text { who underwent } \\
\text { spinal fusion } \\
\text { surgery (at } 7 \\
\text { institutions) }\end{array}$ & $\begin{array}{l}\text { Clinical data of patient, } \\
\text { laboratory, and surgical } \\
\text { characteristics }\end{array}$ & $\begin{array}{l}\text { Univariate and multivariate } \\
\text { regression analysis to identify } \\
\text { factors associated with } \\
\text { infection development }\end{array}$ & $\begin{array}{l}6.4 \% \text { patients developed deep } \\
\text { wound infection; factors associated } \\
\text { with deep wound infection: } \\
\text { presence of a gastrostomy/ } \\
\text { gastrojejunostomy tube }\end{array}$ & \\
\hline He et al. (70) & $\begin{array}{l}61 \text { pts with spastic } \\
\text { CP }\end{array}$ & $\begin{array}{l}\text { Serial R- and S-baclofen } \\
\text { plasma concentrations }\end{array}$ & $\begin{array}{l}\text { Mixed-effects population } \\
\text { model and a 2-compartment } \\
\text { model used for population } \\
\text { pharmacokinetics analysis } \\
\text { of oral baclofen; a final } \\
\text { multivariable model used to } \\
\text { describe oral baclofen profiles }\end{array}$ & $\begin{array}{l}\text { Mean population estimate of } \\
\text { apparent clearance/F: } 0.273 \mathrm{~L} / \mathrm{h} / \\
\mathrm{kg} \text { with } 33.4 \% \text { IIV; apparent volume } \\
\text { of distribution (Vss/F): } 1.16 \mathrm{~L} / \mathrm{kg} \\
\text { with } 43.9 \% \text { IIV; average baclofen } \\
\text { terminal half-life: } 4.5 \mathrm{~h}\end{array}$ & $\begin{array}{l}\text { Determinants of apparent } \\
\text { clearance: body weight, } \\
\text { a possible genetic factor, } \\
\text { and age }\end{array}$ \\
\hline
\end{tabular}


TABLE 2 | Continued

\begin{tabular}{|c|c|c|c|c|c|}
\hline Study & Subject sample & Data & Methods & Main findings & Other findings \\
\hline $\begin{array}{l}\text { Kato et al. } \\
(71)\end{array}$ & $\begin{array}{l}31 \text { pts with CP and } \\
\text { cervical myelopathy; } \\
30 \text { with CSM, all pts } \\
\text { underwent posterior } \\
\text { decompression } \\
\text { surgery }\end{array}$ & $\begin{array}{l}\text { Measurements of pedicle and } \\
\text { placement of pedicle screws } \\
\text { from CT scans }\end{array}$ & $\begin{array}{l}\text { Multivariate analysis used to } \\
\text { evaluate factors associated } \\
\text { with the breach of cervical } \\
\text { pedicle screws }\end{array}$ & $\begin{array}{l}23 \% \text { CP pts and } 7 \% \text { CSM pts had } \\
\text { pedicle sclerosis; pedicle sclerosis } \\
\text { associated with a higher risk of } \\
\text { breach }\end{array}$ & \\
\hline $\begin{array}{l}\text { Kruijsen- } \\
\text { Terpstra et al. } \\
\text { (72) }\end{array}$ & $\begin{array}{l}92 \text { pts ( } 2 \text { years old) } \\
\text { with CP }\end{array}$ & $\begin{array}{l}\text { Longitudinal data (type of } \\
\text { CP, GMFCS level, intellectual } \\
\text { capacity, whether epilepsy, } \\
\text { etc.) }\end{array}$ & $\begin{array}{l}\text { Multivariate analysis used } \\
\text { to identify determinants of } \\
\text { development of self-care and } \\
\text { mobility activities }\end{array}$ & $\begin{array}{l}\text { Determinants of development of } \\
\text { self-care activities: GMFCS and } \\
\text { intellectual capacity; determinant of } \\
\text { development of mobility activities: } \\
\text { GMFCS }\end{array}$ & $\begin{array}{l}\text { Self-care and mobility } \\
\text { activity changes were } \\
\text { less favorable in pts with } \\
\text { severe CP }\end{array}$ \\
\hline $\begin{array}{l}\text { Shore et al. } \\
(73)\end{array}$ & $\begin{array}{l}320 \text { children with } \\
\text { CP who underwent } \\
\text { VDRO for treatment } \\
\text { of hip displacement }\end{array}$ & $\begin{array}{l}\text { Clinical data (Age, sex, } \\
\text { GMFCS, preoperative } \\
\text { radiography, use of botulinum } \\
\text { toxin, surgical performance, } \\
\text { surgeon volume, etc.) }\end{array}$ & $\begin{array}{l}\text { Univariate and multivariate } \\
\text { (Cox regression) analyses } \\
\text { used to determine effects of } \\
\text { the data variables on surgical } \\
\text { success; Kaplan-Meier } \\
\text { survivorship curve generated }\end{array}$ & $\begin{array}{l}92 \% \text { success rate for GMFCS } \\
\text { levels I and II vs. } 76 \% \text { success } \\
\text { rate for GMFCS level V; predictor } \\
\text { of surgical success: soft-tissue } \\
\text { release at VDRO }\end{array}$ & $\begin{array}{l}37 \% \text { surgical failure; } \\
\text { predictors of surgical } \\
\text { revision: younger age at } \\
\text { surgery, increased GMFCS } \\
\text { level, and lower annual } \\
\text { surgical hip volume }\end{array}$ \\
\hline Mo et al. (74) & $\begin{array}{l}206 \text { children with } \\
\text { CP who underwent } \\
\text { surgical scoliosis } \\
\text { correction }\end{array}$ & $\begin{array}{l}\text { Clinical data (age, motor } \\
\text { deficits, seizure history, verbal } \\
\text { communication, mental } \\
\text { retardation, Hydrocephalus } \\
\text { severity, etc.) }\end{array}$ & $\begin{array}{l}\text { Univariate and multivariate } \\
\text { logistic regression used to } \\
\text { identify factors causing poor } \\
\text { IONM signals }\end{array}$ & $\begin{array}{l}\text { Predictors of poor IONM } \\
\text { signals: PVL, hydrocephalus, } \\
\text { encephalomalacia; predictors of } \\
\text { no signals: moderate or marked } \\
\text { hydrocephalus, encephalomalacia }\end{array}$ & $\begin{array}{l}\text { Predictors of no motor } \\
\text { signal: focal PVL, } \\
\text { moderate or marked } \\
\text { hydrocephalus, } \\
\text { encephalomalacia; } \\
\text { predictors of no sensory } \\
\text { signal: moderate } \\
\text { hydrocephalus }\end{array}$ \\
\hline $\begin{array}{l}\text { Grecco et al. } \\
(75)\end{array}$ & $\begin{array}{l}56 \text { children with } \\
\text { spastic CP }\end{array}$ & $\begin{array}{l}\text { Clinical and neurophysiologic } \\
\text { data (age, gross motor } \\
\text { function, laterality of motor } \\
\text { impairment, injury location } \\
\text { and MEP) }\end{array}$ & $\begin{array}{l}\text { Univariate and multivariate } \\
\text { logistic regression analyses } \\
\text { used to identify predictors of } \\
\text { tDCS responses }\end{array}$ & $\begin{array}{l}\text { Predictors of good responses } \\
\text { to tDCS (and gait training): MEP } \\
\text { (for } 6 \text {-min walk test and gait } \\
\text { speed), and subcortical injury (for } \\
\text { gait kinematics and gross motor } \\
\text { function) }\end{array}$ & $\begin{array}{l}\text { The interaction of } \\
\text { MEP and brain injury } \\
\text { location predicted the } \\
\text { responsiveness of tDCS }\end{array}$ \\
\hline $\begin{array}{l}\text { Minhas et al. } \\
(76)\end{array}$ & $\begin{array}{l}1,746 \text { pts who } \\
\text { underwent } \\
\text { orthopedic } \\
\text { procedure ( } 345 \text { pts } \\
\text { underweight, } 952 \\
\text { pts normal weight, } \\
209 \text { overweight, } \\
240 \text { obese) }\end{array}$ & $\begin{array}{l}\text { Clinical data (whether } \\
\text { seizure, whether asthma, } \\
\text { whether use steroid, surgical } \\
\text { procedure, etc.) }\end{array}$ & $\begin{array}{l}\text { Multivariate logistic regressions } \\
\text { performed to evaluate the } \\
\text { effect of } \mathrm{BMI} \text { on complications }\end{array}$ & $\begin{array}{l}\text { Risk factors for total and medical } \\
\text { complications in spine, hip, and } \\
\text { lower extremity procedures: } \\
\text { underweight class }\end{array}$ & $\begin{array}{l}\text { Weight was not } \\
\text { associated with } \\
\text { complications in tendon } \\
\text { procedures; overweight } \\
\text { and obesity not } \\
\text { associated with increased } \\
\text { risk for complications }\end{array}$ \\
\hline $\begin{array}{l}\text { Galarraga } \\
\text { et al. (77) }\end{array}$ & $\begin{array}{l}115 \text { children with } \\
\text { CP who underwent } \\
\text { (hip, ankle, foot, } \\
\text { etc.) surgery }\end{array}$ & $\begin{array}{l}\text { Preoperative data ( } 36 \\
\text { physical examination } \\
\text { variables and gait kinematics) } \\
\text { and surgery data }\end{array}$ & $\begin{array}{l}\text { PCA data dimension reduction; } \\
\text { multi-regression analysis used } \\
\text { to predict postoperative lower } \\
\text { limb kinematics }\end{array}$ & $\begin{array}{l}\text { Based on the kinematic angle, } \\
\text { mean prediction errors on test vary } \\
\text { from } 4^{\circ} \text { (pelvic obliquity and hip } \\
\text { adduction) to } 10^{\circ} \text { (hip rotation and } \\
\text { foot progression) }\end{array}$ & $\begin{array}{l}\text { Mean prediction errors are } \\
\text { smaller than the variability } \\
\text { of gait parameters }\end{array}$ \\
\hline $\begin{array}{l}\text { Mann et al. } \\
(78)\end{array}$ & 128 pts with CP & $\begin{array}{l}\text { Physical activity, physical, } \\
\text { psychosocial and total QOL } \\
\text { reported by parents, walking } \\
\text { performance measured by a } \\
\text { StepWatch device }\end{array}$ & $\begin{array}{l}\text { Multivariate regression used } \\
\text { to examine the relationship of } \\
\text { physical activity and walking } \\
\text { performance to QOL }\end{array}$ & $\begin{array}{l}\text { Physical activity positively } \\
\text { associated with physical and } \\
\text { total QOL; walking performance } \\
\text { positively associated with physical } \\
\text { QOL }\end{array}$ & $\begin{array}{l}\text { Participation level } \\
\text { positively associated with } \\
\text { psychosocial QOL }\end{array}$ \\
\hline
\end{tabular}

AFO, ankle foot orthosis; AHA, assisting hand assessment; ANN, artificial neural networks; BMI, body mass index; CP, cerebral palsy; CSM, cervical spondylotic myelopathy; DTW, dynamic time warping; EMG, electromyographic; ENIGMA, enhanced interactive general movement assessment; GMFCS, Gross Motor Function Classification System; ICU, intensive care unit; IIV, interindividual variability; IONM, intraoperative neuromonitoring; MEP, motor-evoked potential; NN, neural networks; NNC, nearest neighbor classifier; Pts, patients; PVL, periventricular leukomalacia; QOL, quality of life; ROC, receiver operating characteristics; SDR, selective dorsal rhizotomy; surgeon volume, the number of procedures performed; SVM, support vector machines; tDCS, transcranial direct current stimulation; VDRO, proximal femoral varus derotation osteotomy.

movement assessment studies are small $(n=4-15)$, studies with large samples are needed to further verify and improve these machine-learning methods. Further, the performance of these machine-learning studies or classification systems may be improved by optimizing the data processing chains (feature extraction, feature selection, classification, and verification). For details on optimizing data processing chains to improve classification performance, see Ref. (79).

Recently, Marschik et al. proposed an integrated system called a fingerprint model that monitors the movement and 
speech-language development of new-born babies and infants at risk and automatically detects neurodevelopmental disorders such as CP by multidimensional data analysis and machinelearning approaches (13). Although it is challenging (in technical details), the fingerprint model enables neurological assessment of at-risk infants in an objective and quantitative manner and facilitates early detection of CP and other neurodevelopmental disorders, which may be the future direction of pediatric clinical practice.

\section{MULTIVARIATE ANALYSIS IN CP OUTCOME EVALUATION}

Although there is no cure for $\mathrm{CP}$, currently, treatment effects and outcomes in CP patients have been studied extensively. Multivariate approaches have been applied to outcome assessment (including survival analysis) in CP, and Table 2 (the latter part) provides a summary of these studies (62-78). The majority of the outcome studies employed a two-step approach: first, univariate analysis is used to identify variables that are associated with outcome; second, multivariate analysis is used to further examine the variables indicated by the univariate analysis and identify outcome predictors. A large sample of children with CP $(n=4,007)$ in UK were studied, and multivariate survival analysis indicated that the death rate was $\sim 8,85-94 \%$ of the children survived to age 20 years old, and the best predictors of CP survival were the number and severity of impairments (62). The multivariate outcome studies in CP fall into three categories:

(1) outcome evaluation of medication and supportive treatments;

(2) surgical outcome evaluation; and (3) quality of life (QOL) evaluation.

\section{Outcome Evaluation of Medication and Supportive Treatments}

The effect of commonly used medication oral baclofen on children with CP has been assessed with a multivariate model for the population pharmacokinetics analysis $(n=61)$, and it has been found that baclofen dosage based on body weight was appropriate to treat patients ( $\geq 2$ years old), and determinants of apparent clearance in these children included body weight, a possible genetic factor, and age (70). Plasticity (shown as increased FA in the CSTs on DTI and improved motor function measures) induced by combined therapy (botulinum followed by physiotherapy) in children with spastic quadriplegia $(n=8)$ has been reported (80), while a later DTI study indicated that the addition of botulinum to physiotherapy did not influence the outcome at 6 months in children with spastic diplegic CP $(n=18)$ (81). DTI has also been used to evaluate the motor function outcomes of hemiplegic CP patients after rehabilitation treatment and DTI measurements such as the fiber number and FA of bilateral CSTs were correlated with functional level of hemiplegia scale (82). The quality of exercises in CP physical therapy has been evaluated with several classifiers, and AdaBoosted decision tree obtained good detection rate of exercise errors (61). In addition, multivariate outcome evaluation of therapies such as transcranial direct current stimulation (tDCS) has been performed (75).
Grecco et al. investigated the functional outcome of tDCS in children with CP $(n=56)$, and multivariate logistic regression analyses identified that the presence of motor evoked potential was a predictor for walk test and gait speed, subcortical injury was a predictor for gross motor function, and both of them were predictors of motor function gain arise from tDCS combined with gait training in these patients (75). However, there are few outcome studies of medications and supportive treatments in $\mathrm{CP}$ using multivariate analyses, and multivariate analysis may play a bigger role in such outcome evaluation to reveal the true therapeutic effects of these treatments and their outcomes in $\mathrm{CP}$ patients.

\section{Surgical Outcome Evaluation}

A number of multivariate studies have investigated the outcomes of surgical procedures in CP $(63,64,67,71,74-77)$. For example, the outcomes of SDR surgery have been studied in children with CP and outcome-associated factors have been identified $(63,64)$. Kim et al. examined factors associated with poor outcome of SDR surgery in pediatric patients with $\mathrm{CP}$ ( $n=174)$ using multivariate logistic regression, and found that the poor-outcome rate was $6.3 \%$, and the type of CP disability (diplegia, quadriplegia, etc.) was the predictor of poor outcome after SDR surgery (63). Further, Golan et al. evaluated the risk of spinal deformity in children with CP after SDR surgery $(n=98)$ and multivariate regression analysis identified several risk factors for spinal deformity: CP severity, ambulatory function, age at surgery, and gender (64). In addition, Long et al. investigated intraoperative opioid dosing and associated outcomes with multivariate regression in children with $\mathrm{CP}(n=71)$ who underwent orthopedic surgery and reported that less intraoperative opioid was administered to CP children than non-CP children, and intraoperative opioid dosing was the outcome predictor of postoperative oxygen desaturation and ICU admission (67). Shore et al. examined the surgical outcome of children with CP $(n=320)$ who underwent proximal femoral varus derotation osteotomy (VDRO) for treatment of hip displacement, and found that success rate was $92 \%$ for GMFCS levels I and II vs. $76 \%$ for GMFCS level V, and multivariate analysis indicated that soft-tissue release during the VDRO procedure was the predictor of surgical success (73). The surgical outcome predictors identified by these studies are useful for outcome prediction for individual CP patients.

Complications after CP surgical treatments have also been investigated. Using multivariate regression analysis, Sponseller et al. studied deep wound infection after spinal fusion surgery at seven institutions in pediatric patients with CP $(n=204)$ and found that $6.4 \%$ of patients developed deep wound infection following surgery, and presence of a gastrostomy/gastrojejunostomy tube was the factor associated with infection (69). In addition, Kato et al. investigated cervical spine in patients with athetoid CP who underwent posterior decompression surgery $(n=31)$ and multivariate analysis showed that pedicle sclerosis associated with a higher risk of breach of cervical pedicle screws (71). Further, Minhas et al. evaluated the effect of body mass index class on complications after orthopedic surgery in children with CP $(n=1,746)$ and multivariate 
logistic regression analysis revealed that underweight status was the risk factor for complications in osteotomies and spine surgery (76). The risk factors identified by these studies are helpful to avoid the surgical complications and improve surgical treatments in CP.

In children with $\mathrm{CP}$ who underwent surgery, intraoperative neuromonitoring (IONM) often fail (failure rate 61\%) (74). Mo et al. studied IONM in children with CP who underwent surgical scoliosis correction $(n=206)$ and multivariate logistic regression analysis revealed that PVL, hydrocephalus, and encephalomalacia were the predictors of poor IONM signals, while moderate or marked hydrocephalus and encephalomalacia were the predictors of no signals (74). Further, outcome prediction of CP surgical procedures has been explored in a recent study. Galarraga et al. examined children with CP who underwent (hip, ankle, foot, etc.) surgery $(n=115)$, and multi-regression analysis revealed that preoperative and surgical data could predict postoperative kinematics, and mean prediction errors (varying from $4^{\circ}$ to $10^{\circ}$ ) were smaller compared with the variability of gait parameters (77). These results are encouraging because they indicated that the postsurgical kinematics of patients with CP could be predicted (relatively accurately with small mean prediction errors) using presurgical and surgical data, which allows an estimate of postsurgical outcome ahead of time.

\section{QOL Evaluation}

Quality of life in physical ability, intellectual ability, self-care, and other aspects of life is an important outcome in CP. Multivariate analysis has been frequently used to assess QOL in patients with CP $(65,66,68,72,78)$, and factors associated with physical QOL and self-care have been identified. For example, a multivariate analysis on QOL data of infants with CP $(n=92)$ identified GMFCS and intellectual capacity as the associated factors of self-care activity development, and GMFCS as the associated factors of mobility activities development (72). Further, a recent multivariate analysis showed that physical activity was positively associated with physical and total QOL in patients with $\mathrm{CP}$ ( $n=128)$, and walking performance was positively associated with physical QOL (78). The factors identified by these studies may improve the QOL of patients with CP.

Taken together, since there is no cure for CP yet, and the death rate of $\mathrm{CP}$ is high $(\sim 8 \%)$, there is much to do to improve the outcomes of $\mathrm{CP}$, and multivariate analytic approaches may play a bigger role in meeting such clinical demands. Surgical outcome predictors and risk factors for complications in CP surgical treatments have been identified by a number of multivariate outcome

\section{REFERENCES}

1. Herskind A, Greisen G, Nielsen JB. Early identification and intervention in cerebral palsy. Dev Med Child Neurol (2015) 57(1):29-36. doi:10.1111/dmcn. 12531

2. McIntyre S, Morgan C, Walker K, Novak I. Cerebral palsy - don't delay. Dev Disabil Res Rev (2011) 17:114-29. doi:10.1002/ddrr.1106

3. Novak I, Hines M, Goldsmith S, Barclay R. Clinical prognostic messages from a systematic review about cerebral palsy. Pediatrics (2012) 130:e1285-312. doi:10.1542/peds.2012-0924 studies $(63,64,67,69,71,73,76)$, which are useful not only for outcome evaluation and prediction but also for avoiding complications and improving surgical treatments in CP. However, there are few outcome studies for medications and supportive treatments (such as physical therapy) in CP using multivariate analysis. Thus, further research is needed to evaluate the outcomes of medications and supportive treatments, and multivariate analysis may play a bigger role in such outcome evaluation to reveal the true therapeutic effects of these treatments and their outcomes in $\mathrm{CP}$ patients, and help improve the outcomes of these treatments for patients with CP.

\section{SUMMARY}

Multivariate analysis has been applied to several areas in CP research such as identification of risk factors for $\mathrm{CP}$, detection of $\mathrm{CP}$ and identification of $\mathrm{CP}$ abnormalities, movement assessment for CP prediction, and outcome assessment. The studies reviewed in this paper have demonstrated that multivariate analytic and ML approaches have made it possible to analyze movement recordings and identify $\mathrm{CP}$ movement impairments automatically. In addition, outcome predictors for surgical treatments have been identified by multivariate outcome studies. To make the multivariate analytic and ML approaches useful in clinical settings, further research with large samples is needed to verify and improve these methods in $\mathrm{CP}$ detection, movement assessment, and outcome evaluation/prediction. As multivariate analysis, ML and data processing technologies advance in the era of Big Data, it is expected that multivariate analysis and $\mathrm{ML}$ will play a bigger role in improving the diagnosis and treatment of $\mathrm{CP}$ to reduce mortality and morbidity rates, and enhance patient care for children with CP.

\section{AUTHOR CONTRIBUTIONS}

JZ reviewed the multivariate analytic studies in cerebral palsy and wrote up the manuscript.

\section{ACKNOWLEDGMENTS}

This work was inspired by the clinical team led by Dr. Manish Shah at the University of Texas Health Science Center (in Houston) and affiliated hospitals who are dedicated to patient care for children with cerebral palsy. Proofread was kindly provided by Drs. Gary and Carla Brandenburger.

4. Reid S, Carlin J, Reddihough D. Distribution of motor types in cerebral palsy: how do registry data compare? Dev Med Child Neurol (2011) 53:233-8. doi:10.1111/j.1469-8749.2010.03844.x

5. NIH (National Institute of Neurological Disorders and Stroke). Cerebral Palsy: Hope through Research. (2017). Available from: https://www.ninds. nih.gov/Disorders/Patient-Caregiver-Education/Hope-Through-Research/ Cerebral-Palsy-Hope-Through-Research\#3104_2

6. Krageloh-Mann I, Horber V. The role of magnetic resonance imaging in elucidating the pathogenesis of cerebral palsy: a systematic review. Dev Med Child Neurol (2007) 49:144-51. doi:10.1111/j.1469-8749.2007.00144.x 
7. Prechtl HFR. Qualitative changes of spontaneous movements in fetus and preterm infant are a marker of neurological dysfunction. Early Hum Dev (1990) 23(3):151-8. doi:10.1016/0378-3782(90)90011-7

8. Einspieler C, Prechtl HFR. Prechtl's assessment of general movements: a diagnostic tool for the functional assessment of the young nervous system. Ment Retard Dev Disabil Res Rev (2005) 11:61-7. doi:10.1002/mrdd.20051

9. Einspieler C, Marschik PB, Bos AF, Ferrari F, Cioni G, Prechtl HFR. Early markers for cerebral palsy: insights from the assessment of general movements. Future Neurol (2012) 7(6):709-17. doi:10.2217/fnl.12.60

10. Spittle AJ, Orton J. Cerebral palsy and developmental coordination disorder in children born preterm. Semin Fetal Neonatal Med (2013) 19(2):84-9. doi:10.1016/j.siny.2013.11.005

11. Bosanquet M, Copeland L, Ware R, Boyd R. A systematic review of tests to predict cerebral palsy in young children. Dev Med Child Neurol (2013) 55(5):418-26. doi:10.1111/dmcn.12140

12. Marcroft C, Khan A, Embleton ND, Trenell M, Plötz T. Movement recognition technology as a method of assessing spontaneous general movements in high risk infants. Front Neurol (2015) 5:284. doi:10.3389/fneur.2014.00284

13. Marschik PB, Pokorny FB, Peharz R, Zhang D, O’Muircheartaigh J, Roeyers H, et al. A novel way to measure and predict development: a heuristic approach to facilitate the early detection of neurodevelopmental disorders. Curr Neurol Neurosci Rep (2017) 17(5):43. doi:10.1007/s11910-017-0748-8

14. Levman J, Takahashi E. Multivariate analyses applied to fetal, neonatal and pediatric MRI of neurodevelopmental disorders. Neuroimage Clin (2015) 9:532-44. doi:10.1016/j.nicl.2015.09.017

15. Levman J, Takahashi E. Pre-adult MRI of brain cancer and neurological injury: multivariate analyses. Front Pediatr (2016) 4:65. doi:10.3389/fped.2016.00065

16. McLachlan GJ. Discriminant Analysis and Statistical Pattern Recognition. Hoboken, NJ: Wiley Interscience (2004).

17. Vapnik VN. The Nature of Statistical Learning Theory. New York: Springer (1995).

18. Yegnanarayana B. Artificial Neural Networks. New Delhi: PHI Learning Pvt. Ltd (2009)

19. Breiman L. Random forests. Mach Learn (2001) 45:5-32. doi:10.1023/ A:1010933404324

20. Manton KG, Lowrimore G, Yashin A, Kovtun M. Cluster Analysis: Overview. Hoboken, NJ: Wiley StatsRef: Statistics Reference Online (2014).

21. Cummins SK, Nelson KB, Grether JK, Velie EM. Cerebral palsy in four northern California counties, births 1983 through 1985. J Pediatr (1993) 123(2):230-7. doi:10.1016/S0022-3476(05)81693-2

22. Pinto-Martin JA, Riolo S, Cnaan A, Holzman C, Susser MW, Paneth N. Cranial ultrasound prediction of disabling and nondisabling cerebral palsy at age two in a low birth weight population. Pediatrics (1995) 95(2):249-54.

23. Bax M, Tydeman C, Flodmark O. Clinical and MRI correlates of cerebral palsy: the European Cerebral Palsy Study. JAMA (2006) 296(13):1602-8. doi:10.1001/jama.296.13.1602

24. Allan WC, Vohr B, Makuch RW, Katz KH, Ment LR. Antecedents of cerebral palsy in a multicenter trial of indomethacin for intraventricular hemorrhage. Arch Pediatr Adolesc Med (1997) 151(6):580-5. doi:10.1001/ archpedi.1997.02170430046010

25. Kim JN, Namgung R, Chang W, Oh CH, Shin JC, Park ES, et al. Prospective evaluation of perinatal risk factors for cerebral palsy and delayed development in high risk infants. Yonsei Med J (1999) 40(4):363-70. doi:10.3349/ ymj.1999.40.4.363

26. Golomb MR, Garg BP, Saha C, Azzouz F, Williams LS. Cerebral palsy after perinatal arterial ischemic stroke. JChild Neurol (2008) 23(3):279-86. doi:10.1177/0883073807309246

27. Han TR, Bang MS, Lim JY, Yoon BH, Kim IW. Risk factors of cerebral palsy in preterm infants. Am J Phys Med Rehabil (2002) 81(4):297-303. doi:10.1097/00002060-200204000-00011

28. Zhong Y, Wu J, Wu K, Wen R, Hou G, Peng D, et al. Evaluation of risk factors associated with cerebral palsy in children of Leshan Prefecture, Sichuan: a case control study on 308 cases. Zhonghua Yu Fang Yi Xue Za Zhi (2002) 36(5):323-6.

29. Miamoto CB, Pereira LJ, Paiva SM, Pordeus IA, Ramos-Jorge ML, Marques LS. Prevalence and risk indicators of temporomandibular disorder signs and symptoms in a pediatric population with spastic cerebral palsy. J Clin Pediatr Dent (2011) 35(3):259-63. doi:10.17796/jcpd.35.3.738t75v74l1m1p22
30. Abdullahi H, Satti M, Rayis DA, Imam AM, Adam I. Intra-partum fever and cerebral palsy in Khartoum, Sudan. BMC Res Notes (2013) 24(6):163. doi:10.1186/1756-0500-6-163

31. Yu T, Rong L, Wang Q, You Y, Fu JX, Kang LM, et al. Influence of neonatal diseases and treatments on the development of cerebral palsy in preterm infant. Sichuan Da Xue Xue Bao Yi Xue Ban (2013) 44(2):270-3.

32. Golomb MR, Saha C, Garg BP, Azzouz F, Williams LS. Association of cerebral palsy with other disabilities in children with perinatal arterial ischemic stroke. Pediatr Neurol (2007) 37(4):245-9. doi:10.1016/j.pediatrneurol.2007. 06.003

33. Griffiths PD, Radon MR, Crossman AR, Zurakowski D, Connolly DJ. Anatomic localization of dyskinesia in children with "profound" perinatal hypoxicischemic injury. AJNR Am J Neuroradiol (2010) 31(3):436-41. doi:10.3174/ ajnr.A1854

34. Yoshida S, Hayakawa K, Yamamoto A, Okano S, Kanda T, Yamori Y, et al. Quantitative diffusion tensor tractography of the motor and sensory tract in children with cerebral palsy. Dev Med Child Neurol (2010) 52(10):935-40. doi:10.1111/j.1469-8749.2010.03669.x

35. Coppola G, Fortunato D, Mainolfi C, Porcaro F, Roccaro D, Signoriello G, et al. Bone mineral density in a population of children and adolescents with cerebral palsy and mental retardation with or without epilepsy. Epilepsia (2012) 53(12):2172-7. doi:10.1111/j.1528-1167.2012.03639.x

36. Benfer KA, Weir KA, Bell KL, Ware RS, Davies PS, Boyd RN. Oropharyngeal dysphagia and gross motor skills in children with cerebral palsy. Pediatrics (2013) 131(5):e1553-62. doi:10.1542/peds.2012-3093

37. Romeo DM, Brogna C, Musto E, Baranello G, Pagliano E, Casalino T, et al. Sleep disturbances in preschool age children with cerebral palsy: a questionnaire study. Sleep Med (2014) 15(9):1089-93. doi:10.1016/j.sleep.2014.05.008

38. Adler C, Berweck S, Lidzba K, Becher T, Staudt M. Mirror movements in unilateral spastic cerebral palsy: specific negative impact on bimanual activities of daily living. Eur J Paediatr Neurol (2015) 19(5):504-9. doi:10.1016/j. ejpn.2015.03.007

39. Tao W, Zhang X, Chen X, Wu D, Zhou P. Multi-scale complexity analysis of muscle coactivation during gait in children with cerebral palsy. Front Hum Neurosci (2015) 9:367. doi:10.3389/fnhum.2015.00367

40. Ghate D, Vedanarayanan V, Kamour A, Corbett JJ, Kedar S. Optic nerve morphology as marker for disease severity in cerebral palsy of perinatal origin. J Neurol Sci (2016) 368:25-31. doi:10.1016/j.jns.2016.06.029

41. Reid LB, Cunnington R, Boyd RN, Rose SE. Surface-based fMRI-driven diffusion tractography in the presence of significant brain pathology: a study linking structure and function in cerebral palsy. PLoS One (2016) 11(8):e0159540. doi:10.1371/journal.pone. 0159540

42. Tosun A, Erisen Karaca S, Unuvar T, Yurekli Y, Yenisey C, Omurlu IK. Bone mineral density and vitamin D status in children with epilepsy, cerebral palsy, and cerebral palsy with epilepsy. Childs Nerv Syst (2017) 33(1):153-8. doi:10.1007/s00381-016-3258-0

43. Kayem G, Mandelbrot L, Haddad B. Use of magnesium sulfate in obstetrics. Gynecol Obstet Fertil (2012) 40(10):605-13. doi:10.1016/j.gyobfe.2012.08.005

44. Crowther CA, Middleton PF, Voysey M, Askie L, Duley L, Pryde PG, et al. Assessing the neuroprotective benefits for babies of antenatal magnesium sulphate: an individual participant data meta-analysis. PLoS Med (2017) 14(10):e1002398. doi:10.1371/journal.pmed.1002398

45. Jacobs SE, Tarnow-Mordi WO. Therapeutic hypothermia for newborn infants with hypoxic-ischaemic encephalopathy. J Paediatr Child H(2010) 46:568-76. doi:10.1111/j.1440-1754.2010.01880.x

46. Thomas B, Eyssen M, Peeters R, Molenaers G, Van Hecke P, De Cock P, et al. Quantitative diffusion tensor imaging in cerebral palsy due to periventricular white matter injury. Brain (2005) 128(Pt 11):2562-77. doi:10.1093/brain/ awh600

47. Hoon AH Jr, Stashinko EE, Nagae LM, Lin DD, Keller J, Bastian A, et al. Sensory and motor deficits in children with cerebral palsy born preterm correlate with diffusion tensor imaging abnormalities in thalamocortical pathways. Dev Med Child Neurol (2009) 51(9):697-704. doi:10.1111/j. 1469-8749.2009.03306.x

48. Scheck SM, Boyd RN, Rose SE. New insights into the pathology of white matter tracts in cerebral palsy from diffusion magnetic resonance imaging: a systematic review. Dev Med Child Neurol (2012) 54(8):684-96. doi:10.1111/j.1469-8749.2012.04332.x 
49. Wilke M, Staudt M. Does damage to somatosensory circuits underlie motor impairment in cerebral palsy? Dev Med Child Neurol (2009) 51:686-7. doi:10.1111/j.1469-8749.2009.03332.x

50. Ziv E, Tymofiyeva O, Ferriero DM, Barkovich AJ, Hess CP, Xu D. A machine learning approach to automated structural network analysis: application to neonatal encephalopathy. PLoS One (2013) 8(11):e78824. doi:10.1371/journal. pone. 0078824

51. Cabrerizo M, Ayala M, Goryawala M, Jayakar P, Adjouadi M. A new parametric feature descriptor for the classification of epileptic and control EEG records in pediatric population. Int J Neural Syst (2012) 22:1250001. doi:10.1142/ S0129065712500013

52. Meinecke L, Breitbach-Faller N, Bartz C, Damen R, Rau G, Disselhorst-Klug C. Movement analysis in the early detection of newborns at risk for developing spasticity due to infantile cerebral palsy. Hum Mov Sci (2006) 25(2):125-44. doi:10.1016/j.humov.2005.09.012

53. Berge PR, Adde L, Espinosa G, Stavdahl Ø. ENIGMA - enhanced interactive general movement assessment. Expert Syst Appl (2008) 34(4):2664-72. doi:10.1016/j.eswa.2007.05.024

54. Adde L, Helbostad JL, Jensenius AR, Taraldsen G, Grunewaldt KH, Støen R. Early prediction of cerebral palsy by computer-based video analysis of general movements: a feasibility study. Dev Med Child Neurol (2010) 52(8):773-8. doi:10.1111/j.1469-8749.2010.03629.x

55. Heinze F, Hesels K, Breitbach-Faller N, Schmitz-Rode T, Disselhorst-Klug C. Movement analysis by accelerometry of newborns and infants for the early detection of movement disorders due to infantile cerebral palsy. Med Biol Eng Comput (2010) 48(8):765-72. doi:10.1007/s11517-010-0624-z

56. Alaqtash M, Sarkodie-Gyan T, Yu H, Fuentes O, Brower R, Abdelgawad A. Automatic classification of pathological gait patterns using ground reaction forces and machine learning algorithms. Conf Proc IEEE Eng Med Biol Soc (2011):453-7. doi:10.1109/IEMBS.2011.6090063

57. Karch D, Kang K-S, Wochner K, Philippi H, Hadders-Algra M, Pietz J, et al. Kinematic assessment of stereotypy in spontaneous movements in infants. Gait Posture (2012) 36(2):307-11. doi:10.1016/j.gaitpost.2012.03.017

58. Stahl A, Schellewald C, Stavdahl O, Aamo OM, Adde L, Kirkerod H. An optical flow-based method to predict infantile cerebral palsy. IEEE Trans Neural Syst Rehabil Eng (2012) 20(4):605-14. doi:10.1109/TNSRE.2012.2195030

59. Kanemaru N, Watanabe H, Kihara H, Nakano H, Nakamura T, Nakano J, et al. Jerky spontaneous movements at term age in preterm infants who later developed cerebral palsy. Early Hum Dev (2014) 90(8):387-92. doi:10.1016/j. earlhumdev.2014.05.004

60. Wahid F, Begg R, Sangeux M, Halgamuge S, Ackland DC. The effects of an ankle foot orthosis on cerebral palsy gait: a multiple regression analysis. Conf Proc IEEE Eng Med Biol Soc (2015) 5509-12. doi:10.1109/EMBC.2015. 7319639

61. Parmar P, Morris BT. Measuring the quality of exercises. Conf Proc IEEE Eng Med Biol Soc (2016) 2241-4. doi:10.1109/EMBC.2016.7591175

62. Hemming K, Hutton JL, Colver A, Platt MJ. Regional variation in survival of people with cerebral palsy in the United Kingdom. Pediatrics (2005) 116(6):1383-90. doi:10.1542/peds.2005-0259

63. Kim HS, Steinbok P, Wickenheiser D. Predictors of poor outcome after selective dorsal rhizotomy in treatment of spastic cerebral palsy. Childs Nerv Syst (2006) 22(1):60-6. doi:10.1007/s00381-005-1160-2

64. Golan JD, Hall JA, O'Gorman G, Poulin C, Benaroch TE, Cantin MA, et al. Spinal deformities following selective dorsal rhizotomy. J Neurosurg (2007) 106(6 Suppl):441-9. doi:10.3171/ped.2007.106.6.441

65. Majnemer A, Shevell M, Rosenbaum P, Law M, Poulin C. Determinants of life quality in school-age children with cerebral palsy. JPediatr (2007) 151(5):470-5. doi:10.1016/j.jpeds.2007.04.014

66. White-Koning M, Arnaud C, Dickinson HO, Thyen U, Beckung E, Fauconnier J, et al. Determinants of child-parent agreement in quality-of-life reports: a European study of children with cerebral palsy. Pediatrics (2007) 120(4):e804-14. doi:10.1542/peds.2006-3272

67. Long LS, Ved S, Koh JL. Intraoperative opioid dosing in children with and without cerebral palsy. Paediatr Anaesth (2009) 19(5):513-20. doi:10.1111/j. 1460-9592.2009.02980.x

68. Smits DW, Ketelaar M, Gorter JW, van Schie P, Dallmeijer A, Jongmans $\mathrm{M}$, et al. Development of daily activities in school-age children with cerebral palsy. Res Dev Disabil (2011) 32(1):222-34. doi:10.1016/j.ridd.2010. 09.025

69. Sponseller PD, Jain A, Shah SA, Samdani A, Yaszay B, Newton PO, et al. Deep wound infections after spinal fusion in children with cerebral palsy: a prospective cohort study. Spine (Phila Pa 1976) (2013) 38(23):2023-7. doi:10.1097/ BRS.0b013e3182a83e59

70. HeY,Brunstrom-HernandezJE,ThioLL,LackeyS, Gaebler-SpiraD,KurodaMM, et al. Population pharmacokinetics of oral baclofen in pediatric patients with cerebral palsy. JPediatr (2014) 164(5):1181-8. doi:10.1016/j. jpeds.2014.01.029

71. Kato S, Shoda N, Chikuda H, Seichi A, Takeshita K. Morphological characteristics of cervical spine in patients with athetoid cerebral palsy and the accuracy of pedicle screw placement. Spine (Phila Pa 1976) (2014) 39(8):E508-13. doi:10.1097/BRS.0000000000000234

72. Kruijsen-Terpstra AJ, Ketelaar M, Verschuren O, Smits DW, Jongmans MJ, Gorter JW. Determinants of developmental gain in daily activities in young children with cerebral palsy. Phys Occup Ther Pediatr (2015) 35(3):265-79. doi:10.3109/01942638.2014.957429

73. Shore BJ, Zurakowski D, Dufreny C, Powell D, Matheney TH, Snyder BD. Proximal femoral varus derotation osteotomy in children with cerebral palsy: the effect of age, gross motor function classification system level, and surgeon volume on surgical success. J Bone Joint Surg Am (2015) 97(24):2024-31. doi:10.2106/JBJS.O.00505

74. Mo AZ, Asemota AO, Venkatesan A, Ritzl EK, Njoku DB, Sponseller PD. Why no signals? Cerebral anatomy predicts success of intraoperative neuromonitoring during correction of scoliosis secondary to cerebral Palsy. J Pediatr Orthop (2015) 37(8):e451-8. doi:10.1097/BPO.0000000000000707

75. Grecco LA, Oliveira CS, Galli M, Cosmo C, Duarte Nde A, Zanon N, et al. Spared primary motor cortex and the presence of MEP in cerebral palsy dictate the responsiveness to tDCS during gait training. Front Hum Neurosci (2016) 10:361. doi:10.3389/fnhum.2016.00361

76. Minhas SV, Chow I, Otsuka NY. The effect of body mass index on postoperative morbidity after orthopaedic surgery in children with cerebral palsy. J Pediatr Orthop (2016) 36(5):505-10. doi:10.1097/BPO. 0000000000000475

77. Galarraga COA, Vigneron V, Dorizzi B, Khouri N, Desailly E. Predicting postoperative gait in cerebral palsy. Gait Posture (2017) 52:45-51. doi:10.1016/j. gaitpost.2016.11.012

78. Mann K, Tsao E, Bjornson KF. Physical activity and walking performance: influence on quality of life in ambulatory children with cerebral palsy (CP). J Pediatr Rehabil Med (2016) 9(4):279-86. doi:10.3233/PRM-160395

79. Zhang J. Multivariate analysis in pediatric brain tumor. Int J Radiol Radiat Therapy (2017) 2(6):00045. doi:10.15406/ijrrt.2017.02.00045

80. Chaturvedi SK, Rai Y, Chourasia A, Goel P, Paliwal VK, Garg RK, et al. Comparative assessment of therapeutic response to physiotherapy with or without botulinum toxin injection using diffusion tensor tractography and clinical scores in term diplegic cerebral palsy children. Brain Dev (2013) 35(7):647-53. doi:10.1016/j.braindev.2012.10.012

81. Trivedi R, Gupta RK, Shah V, Tripathi M, Rathore RK, Kumar M, et al. Treatment-induced plasticity in cerebral palsy: a diffusion tensor imaging study. Pediatr Neurol (2008) 39(5):341-9. doi:10.1016/j.pediatrneurol. 2008.07.012

82. Kim JH, Kwon YM, Son SM. Motor function outcomes of pediatric patients with hemiplegic cerebral palsy after rehabilitation treatment: a diffusion tensor imaging study. Neural Regen Res (2015) 10(4):624-30. doi:10.4103/ 1673-5374.155438

Conflict of Interest Statement: The author declares that the research was conducted in the absence of any commercial or financial relationships that could be construed as a potential conflict of interest.

Copyright $\odot 2017$ Zhang. This is an open-access article distributed under the terms of the Creative Commons Attribution License (CC BY). The use, distribution or reproduction in other forums is permitted, provided the original author(s) or licensor are credited and that the original publication in this journal is cited, in accordance with accepted academic practice. No use, distribution or reproduction is permitted which does not comply with these terms. 